\title{
State-Supported Terrorism and the U.S. Courts: Some Foreign Policy Problems
}

\author{
Barry E. Carter \\ Georgetown University Law Center, carter@law.georgetown.edu
}

This paper can be downloaded free of charge from:

https://scholarship.law.georgetown.edu/facpub/521

http://ssrn.com/abstract=2309536

96 Am. Soc'y. Int'I L. Proc. 251-254 (2002)

This open-access article is brought to you by the Georgetown Law Library. Posted with permission of the author. Follow this and additional works at: https://scholarship.law.georgetown.edu/facpub

Part of the Criminal Law Commons, and the Military, War, and Peace Commons 


\section{JUDICIAL RESPONSES TO TERROR: ISSUES, PROBLEMS, AND PROSPECTS}

The panel was convened at 12:30 P.M. on Friday, March 15, by its chair, Jordan J. Paust, Law Foundation Professor, University of Houston Law Center. Professor Paust introduced the panelists: Barry E. Carter, Professor of Law, Georgetown University Law Center; Allan Gerson, Co-Director, George Washington University Peacebuilding and Development Institute; Judge Abraham Sofaer, Hoover Institute, Stanford, and former Legal Adviser, U.S. Department of State; Michael Scharf, Professor of Law, New England School of Law. Opening remarks of the chair led to a lively debate among the panelists about issues set forth in general questions posed by the chair and points and counterpoints expressed during the session. A primary purpose of the panel was to consider possibilities and implications of responding to terror through criminal and civil sanctions in municipal courts. The panel was co-sponsored by the International Criminal Law Interest Group and the International Organizations Interest Group.

\section{Opening Remarks by Jordan J. Paust ${ }^{*}$}

In 1985, the UN General Assembly "[u]nequivocally" condemned "as criminal, all acts, methods and practices of terrorism wherever and by whomever committed." The UN Security Council also "resolutely" condemned "'all acts of terrorism' . . . in all its forms, wherever and by whomever committed." Similar condemnations of terrorism and recognitions that terrorism is an international criminal act, regardless of the motive or the status of the perpetrator, occurred in 1989 and in the $1990 \mathrm{~s} .{ }^{3}$ Yet none of the resolutions defined the terrorism it was proscribing as a matter of international law.

Most recently, UN Security Council Resolution 1373 (Resolution 1373) reaffirmed the Council's "unequivocal condemnation of the terrorist attacks which took place in New York, Washington, DC, and Pennsylvania on September 11, 2001," ${ }^{4}$ and decided that all states must take certain measures against terrorism. Perhaps most important for this panel are the decisions that all states shall "deny safe haven to those who finance, plan, support, or commit terrorist acts, or provide safe havens"; ${ }^{5}$ shall "[e]nsure that any person who participates in the financing, planning, preparation or perpetration of terrorist acts or in supporting terrorist acts is brought to justice and ensure that ... such terrorist acts are established as serious criminal offences in domestic laws and regulations and that the punishment duly reflects the seriousness of such terrorist acts"; ${ }^{6}$ and shall "[a]fford one another the greatest measure of assistance in connection with criminal investigations or criminal proceedings ..., including assistance in obtaining evidence in their possession necessary for the proceedings"; ${ }^{7}$ and the call upon all states to "prevent and suppress terrorist attacks and take action against perpetrators of such acts."

\footnotetext{
- Law Foundation Professor, University of Houston Law Center, and panel chair.

${ }^{1}$ UN GA Res. 40/61, 40 UN GAOR, Supp. No. 53, at 301, UN Doc. A/40/53 (Dec. 9, 1985), reprinted in 25 ILM 239 (1986).

2 UN SC Res. 579, UN SCOR, 40th sess., Res. and Decs. at 24, UN Doc. S/INF/41 (1985), reprinted in 25 ILM 243 (1986).

${ }^{3}$ See, e.g., UN GA Res. 49/60 (1994); UN GA Res. 46/51, 46 UN GAOR at 4, UN Doc. A/46/654 (Dec. 9, 1991 ); Jordan J. Paust, M. Cherif Bassiouni et al., Intermational Criminal Law 995, 1005, 1007 (2d ed. 2000).

${ }^{4}$ SC Res. 1373 (Sept. 28, 2001), reprinted in 40 ILM 1278 (2001).

${ }^{5} I d$. at para. 2(c).

${ }^{6} I d$. at para. 2(e).

${ }^{7} I d$. at para. 2(f).

${ }^{8} I d$. at para. $3(\mathrm{c})$.
} 
Such unequivocal condemnations of terrorism as criminal wherever it occurs, by whomever, and regardless of purpose, provides a clear basis for recognizing universal jurisdiction over terrorist acts under customary international law. Such unequivocal condemnations and the mandates in Resolution 1373 also provide a basis for recognizing nonimmunity with respect to civil and criminal sanction strategies.

A general question to start our discussion is whether such condemnations and Resolution 1373 expand the need and bases for civil or criminal sanctions in domestic legal processes. Further, what purposes might be served by civil sanctions and what consequences might follow from expanded use of civil litigation against terrorists and those who harbor or support terrorists? Are civil remedies an appropriate response to terrorism, especially state-supported terrorism? Should foreign policy control independent judicial power? Given the thrust of Resolution 1373, is the Foreign Sovereign Immunities Act too restrictive, especially Section 1605 (a) (7)? Should frozen assets of terroristsupporting states be made available for execution of judgments? Should there be greater U.S. government cooperation with civil litigants against terrorists and terrorist-supporting states, especially in view of the mandates in Resolution 1373? Would it be hypocritical to decry the harboring and support of nonstate terrorists while denying civil sanctions against states that engage in such conduct?

What general purposes might be served by criminal prosecution? What limits might exist? What consequences might follow? How does Resolution 1373 affect the need for prosecution?

What are the likely advantages and disadvantages of pursuing criminal prosecutions in federal district courts, U.S. military commissions, foreign domestic tribunals, ad hoc tribunals like the Pan Am 103 tribunal, ad hoc tribunals created pursuant to Council decisions (like the international criminal tribunals for Yugloslavia and Rwanda), or the expansion of International Criminal Court jurisdiction (eight years after the treaty comes into effect)?

\section{STATE-SUPPORTED TERRORISM AND THE U.S. COURTS: Some Foreign Policy Problems}

\section{by Barry E. Carter*}

Terrorism is an evil that the United States and other civilized countries should combat aggressively.

Fortunately, these countries have many tools they can use in their fight against terrorism, among them military force (as we have just demonstrated in Afghanistan), covert actions, and a variety of economic sanctions against a country or group that supports terrorists. These sanctions-which would preferably be applied in union with other countries, though unilaterally if necessary - can include freezing assets, as well as ending or limiting U.S. government programs (ranging from landing rights to foreign aid), cutting off exports to or imports from the country supporting terrorists, denying it credit or investment funds, and working in the multilateral banks to block loans to the country.

Clearly the U.S. courts also have a role. For example, individual terrorists should be subject to criminal and civil actions whenever we can obtain jurisdiction.

The more complex questions revolve around suits against foreign states that engage in terrorism or provide material support to terrorists. Amendments that started in 1996

\footnotetext{
* Professor of Law and Director, Program in International Business and Economic Law, Georgetown University Law Center.
} 
to the U.S. Foreign Sovereign Immunities Act (FSIA) now essentially allow a new category of suits against a foreign state by (1) U.S. nationals (2) who are seeking money damages for personal injury or death (3) "that was caused by an act of torture, extrajudicial killing, aircraft sabotage, hostage taking, or the provision of material support or resources ... for such an act if such act or provision of material support is engaged in by an official, employee, or agent of such foreign state while acting within the scope of his or her office, employment, or agency." These suits are an explicit exception to foreign sovereign immunity (new subsection (a) (7) of Section 1605, 28 U.S.C. $\$ 16050$, but the exception is limited to suits against the seven states that are designated by the executive branch of the U.S. government as a state sponsor of terrorism: Cuba, Iran, Iraq, Libya, North Korea, Sudan, and Syria.

A growing number of cases against these states_especially Iran and Iraq-are based on the (a) (7) exception, with many of the suits resulting in very large damage judgments. The initial reaction to these awards, or the possibility of future large awards, might well be that these countries are getting what they deserve, that "they ought to pay a price."

The implementation of this statute, however, raises some important questions for the long term. What follows is a brief analysis of the experience under the statute and the possible future dynamics.

First, given the understandable hesitancy of Iran, Iraq, and Cuba to appear in U.S. courts, U.S. judges have held hearings where only the plaintiffs were represented and then the courts entered default judgments. Recently, some judges have then found damages-compensatory and punitive-that are reaching or exceeding $\$ 300$ million per American life lost. (By way of comparison, the federal compensation fund for the victims of the attacks on September 11 has issued regulations indicating that it will make awards ranging from about $\$ 1$ million to $\$ 4$ million. The victims' estates, though, can also sue terrorists for additional damages.)

Second, the foreign governments that are identified as supporting terrorists and that lose these cases usually have little interest in paying. Moreover, these foreign governments generally have only limited assets in the United States, usually just those frozen when a final rupture occurred in the relations between the two countries. (Countries that might run athwart of U.S. foreign policy learned not to leave substantial assets in the United States after the United States froze about $\$ 12$ billion of Iranian assets during the 1979-1981 hostage crisis.) As a result, successful plaintiffs in these (a) (7) suits are hard-pressed to find attachable assets to satisfy their default judgments.

Third, in reaction to this difficulty of collection, Congress passed a special law (the Victims of Trafficking and Violence Protection Act of 2000). ${ }^{2}$ Pursuant to its terms, the U.S. government has now paid about $\$ 350$ million out of U.S. taxpayer funds to the successful plaintiffs in nine cases against Iran, with the justification that these claims are being subrogated to the U.S. government to collect eventually from Iran. The statute might allow just a few other plaintiffs also to collect from the U.S. government. Not only does this law raise questions about why the government should be paying so much to only a few plain tiffs, but there is no similar provision for compensating later successful plaintiffs against Iran or for covering any judgments against any other terrorist state, except for one case against Cuba. Recognizing this problem, the U.S. Congress in 2001 directed President Bush to submit soon "a legislative proposal to establish a comprehensive program to ensure fair, equitable, and prompt compensation for all United States

\footnotetext{
${ }^{1}$ Foreign Sovereign Immunities Act, 28 U.S.C. $\$ 1605(A)(7)(2002)$.

${ }^{2}$ Victims of Trafficking and Violence Protection Act of 2000, Pub. L. No. 106-386, §2002, 114 Stat. 1464, amending 28 U.S.C. $\$ \S 1606,1610$ note (1994 \& Supp. V1999) [hereinafter Victims Act].
} 
victims of international terrorism ... that occurred or occurs on or after November 1 , 1979."

Fourth, how will new U.S. plaintiffs or even the U.S. government with its subrogated claims receive payment from these foreign governments? Since most terrorist states are unlikely to offer new funds or allow assets to be vulnerable to attachment, it is now likely that successful judgment-creditors must wait until a moderate government takes over in Cuba, Iran, Iraq, or elsewhere. Then, when that moderate government wants to do business with the United States, these judgment-creditors will insist on payment of their large judgments, or will begin to attach that country's assets when commercial activities resume between the United States and that country.

Traditionally, outstanding claims between the United States and another country are often settled by a foreign claims settlement agreement when the two countries resume relations. ${ }^{4}$ These agreements usually protect a foreign country from any liability beyond the agreed loss of frozen or any other assets that the foreign state might agree to contribute.

In the present situation, however, there are serious questions about whether this is reasonable given the large judgments under the (a) (7) exception and the very limited assets now frozen by the U.S. government. The judgment-creditors would strongly object to the executive branch and a Congress that has shown itself to be sympathetic to the American plaintiffs, if a proposed agreement were to provide them just a few cents for each dollar of their judgments. The new foreign government might not have the resources, or might simply be unwilling, to make any major contribution to the settlement. That government might conclude that it is easier to do business with Japan or the European Union.

Also, since these judgments are based on federal law (the FSIA), there is some question whether an executive agreement, whether entered into by the president alone or approved by Congress, could provide that judgment-creditors receive less than full compensation without giving them a takings claim against the U.S. government in the U.S. Court of Claims.

Given all these questions about how the statute is presently implemented, it seems timely to consider possible changes in the (a) (7) exception.

First, the exception now provides that the foreign state be afforded "a reasonable opportunity to arbitrate the claim in accordance with accepted international rules of arbitration" if "the act occurred in the foreign state against which the claim has been brought." ${ }^{25}$ Presumably this reflects a recognition that the foreign state might have reason to question the impartiality of the U.S. courts. Might this provision be expanded to offer reasonable opportunity for international arbitration in any (a) (7) case? Why should arbitration be available if Iran is alleged to support terrorist torture or murder in Iran, but not when Iran is alleged to have supported a terrorist act in Israel or Lebanon?

Second, should there be a cap on the damage awards? Tucked away in the 2000 law that compensated several of the successful plaintiffs was language that repealed a 1998 provision allowing plaintiffs to seek punitive damages against the foreign states. ${ }^{6}$ However, the amendment still allows plaintiffs to seek punitive damages against foreign agencies or instrumentalities, so its impact is not clear. In any case, there might be an argument for limiting total damage awards per victim against foreign states, agencies, or instrumentalities. That way, the likely carryover to successor moderate governments would be less burdensome on future relations.

\footnotetext{
${ }^{3}$ Act Making Appropriations for the Departments of Commerce, Justice, and State, the Judiciary, and Related Agencies for the Fiscal Year Ending September 30, 2001, PL107-77, §626 (Nov. 28, 2001).

${ }^{4}$ See Dames \& Moore v. Regan, 453 U.S. 654, 680-81 (1981).

${ }^{5} 28$ U.S.C. $\$ 1605$ (a) (7) (B) (1).

${ }^{6}$ Victims Act, supra note 2.
} 
Third, as Professor Anne-Marie Slaughter of Harvard Law School has suggested, should (a) (7) essentially be repealed and these suits not be allowed against foreign governments or their agencies and instrumentalities? A related statute, the Flatow amendment, still could allow suits against foreign officials, employees, or agents of these terrorist-supporting states. ${ }^{7}$ That way the judgments are personal to the individuals who supported the terrorist acts and do not continue against a new government with new officials.

Fourth, should the judgments against a terrorist state be conditioned to lapse upon a major change in its government? As part of the condition, the U.S. executive branch would make the determination that there was a sufficiently genuine change. This approach would, incidentally, provide an incentive (though admittedly not a strong one) for these terrorist governments to change. To be sure, the traditional rule in international law is that a successor government succeeds to these debts, but it is not ironclad. Moreover, the FSIA is a U.S. statute and the terms of a damage award under it can be defined by statute.

One success story might be about to occur, where a suit against a terrorist-supporting state has led to that state paying compensation to the estates of the victims. The Qaddafi government of Libya apparently is close to making a substantial payment to the families of about 250 Americans killed when a bomb brought down Pan Am flight 103 over Lockerbie, Scotland, in 1988. An (a) (7) suit is pending. President Qaddafi, apparently seeking to normalize relations not only with Europe but also with the United States, is willing to pay a price of over three billion dollars. Even if a settlement occurs, and the (a) (7) suit deserves some of the credit, it is not clear how the suggested changes to the (a) (7) exception would have discouraged or prevented a similar settlement in the these circumstances.

Above all, just as the U.S. Congress recently asked the Bush Administration for a legislative proposal for a "comprehensive program to ensure fair, equitable, and prompt compensation for all [U.S.] victims of international terrorism," now would seem to be the time to consider seriously some changes in the FSIA.

Terrorism should be fought. Arguably, however, there might be conditions or a limit on large judgments that might miss their intended targets and could hamper future U.S. relations with new, moderate foreign governments.

\section{TERRORISM AS WAR}

\section{by Abraham D. Sofaer*}

The devastating consequences of the attacks of September 11, 2001 led President Bush to declare a "war" on terrorism. The first stage of this war was a full-scale military operation in Afghanistan, which destroyed the Taliban and Al Qaeda as fighting forces, and replaced the Taliban regime with an internationally approved transition government. The operation has had the enthusiastic support of the American people, Congress, the UN Security Council, and most sovereign states. No doubt, the future will hold many surprises, and plenty of complications and disappointments. But clearly, the United States has embarked on a new, and dramatically different policy in dealing with terrorism than it has followed for many years.

\footnotetext{
${ }^{7}$ Pub. L. No. 104-208, $\$ 101$ (c), 110 Stat. 3009-172, (1996), (codified at 28 U.S.C. $\$ 1605$ note). In Hill v. Republic of Iraq, 175 F.Supp.2d 36 (D.D.C. 2001), Judge Jackson issued an order against President Saddam Hussein for $\$ 300$ million in punitive damages in an (a) (7) action brought by several people who had been detained and mistreated in 1990 after the Iraqi invasion of Kuwait. The court characterized Saddam Hussein as "an instrumentality" of Iraq (and hence subject to punitive damages), but the court could also have reached the same result under the Flatow amendment.

* George P. Shultz Distinguished Scholar \& Senior Fellow, Hoover Institution, Stanford University; Professor of Law, by Courtesy, Stanford Law School.
} 
For years now, presidents have denounced terrorist attacks on Americans and promised to "pursue" attackers until they "are brought to justice." What President Bush, Sr. and President Clinton meant when they promised to bring terrorists to "justice," however, was to bring them to trial. They used the FBI to investigate, to seek out evidence, and then to pursue through the criminal process those found to be responsible. The effort was certainly appropriate, legally and morally; terrorism is crime. But it was wholly ineffectual as a way to defend the American people.

\section{Terrorism as Crime}

Modern forms of terrorism began in earnest in the 1960s. The world was still emerging from colonialism and state-sponsored racism. People in South Africa, and in other African states, attacked civilian targets to instill a sense of terror in the white community and white-dominated governments that ruled by force. Catholics in Northern Ireland did the same thing as part of their effort to gain greater rights or to drive out the British government. In India, Israel, and many other states, freedom from British or other control had been won in part through such attacks. In Israel, attacks on Jewish civilians were ongoing, as part of an effort to destroy Israel entirely.

No international consensus then existed that these terrorist acts, including the killing of civilians, were unlawful. Politically motivated violence had a favored position in international affairs, including international law. The United Nations General Assembly (Assembly) debates on terrorism in 1972 illustrate this point. In that year, Japanese terrorists sympathetic to the Palestinian cause attacked travelers in Lod Airport, Israel, killing twenty-eight people and wounding seventy-eight; and PLO terrorists of the Black September organization murdered eleven members of the Israeli Olympic team in Munich. Secretary-General Waldheim called on the Assembly to place on its 1972-1973 agenda an item entitled: "Measures to prevent terrorism and other forms of violence which endanger or take innocent human lives or jeopardize fundamental freedoms." A storm of protest erupted. How could the subject of terrorism be considered without considering its causes? Waldheim backed off. He assured the Assembly that he did not intend to affect principles enunciated by the General Assembly regarding colonial and dependent peoples seeking independence and liberation. During the debates that followed that and later proposals, it became clear that many states regarded acts of terror as lawful when undertaken by persons deprived of basic human rights, dignity, freedom, or independence from foreign occupation.

It was not until December 1985 that the Assembly finally condemned "unequivocally ... as criminal, all acts, methods and practices of terrorism." Even that resolution, however, reaffirmed each people's inalienable right to self-determination and the legitimacy of struggles against colonial and racist regimes and other forms of alien domination. Many state representatives affirmed the right to engage in all necessary actions in these struggles.

Meanwhile, however, the international community began to reach agreement that certain acts were criminal in all circumstances and should confer jurisdiction on all states to prosecute them, or alternatively an obligation to extradite persons charged with such acts to other states for prosecution. This concept as applied to piracy and the slave trade was well established in international law. It was also part of the Genocide Convention, adopted by many states after WWII. The Hague Convention on Hijacking was approved in 1971; it required all ratifying states to make hijackings criminal, regardless of political 
purpose. It was followed by conventions against acts jeopardizing aircraft (1973), for the prevention of attacks on diplomats (1977), the taking of hostages (1979), torture (1984), and maritime terrorism (1988).

\section{Terrorism as Aggression}

The basic problem remained, however: What could be done when states failed to satisfy their obligations under these conventions or other principles of international law? The UN Charter provides that nothing within it shall be read to restrict the "inherent" right of self-defense, ${ }^{1}$ but many international lawyers read the Charter to limit this traditional right by construing it to require, among other things, a conventional attack on the territory of one state by the regular forces of another state. This means that a state could support a group of terrorists in an attack on Americans outside the United States without giving rise to any right for the United States to take military action against it. Moreover, even though states are obliged by UN resolutions to refrain from supporting terrorists or giving them sanctuary from which they can attack other states, the breach of these obligations was not understood to confer authority on a state attacked by such terrorists to take military action on the territory of the state that gave them sanctuary.

Presidents and congresses have rejected these limitations on the use of force, but most scholars, and many governments, have regularly condemned U.S. and other military actions that went beyond conventional doctrine. Perhaps the most astonishing example of this is the UN resolution condemning Israel for rescuing its nationals from Uganda, even though the Idi Amin government was assisting the terrorists.

The Reagan administration was forced to address the proper means for responding to terrorism after a series of attacks on U.S. nationals and interests abroad, beginning with the bombing of the U.S. Embassy in Lebanon in 1982. Administration officials were divided on whether to use force in the nation's self-defense, and in particular whether to act against states that gave support or sanctuary to terrorist groups. Secretary of State George P. Shultz strongly advocated policies to prevent acts of terror against the United States, reasoning that this could be achieved only through proactive means.

After Libya supported attacks by terrorists on civilians at the Rome and Vienna airports in December 1985, killing nineteen, including five Americans, President Reagan warned Libya that the United States regarded it as responsible for such attacks and that they gave rise to the right of self-defense. Secretary Shultz stated our position in terms of state responsibility: "A state which supports terrorist or subversive attacks against another state, or which supports or encourages terrorist planning and other activities within its own territory, is responsible for such attacks. Such conduct can amount to an ongoing armed aggression against the other state under international law." Two months later Libya arranged for terrorists to bomb a disco in Berlin, killing two and wounding some fifty Americans. The United States responded with a military attack on Libyan facilities, including a compound in which Colonel Qadaffi sometimes lived.

\section{Back to the Courts}

When George H. Bush became president in 1989, the doctrine of the Reagan administration was not explicitly abandoned but the policy of responding to terrorist attacks with force was discarded. The turning point was the bombing of Pan Am 103 in that year. Instead of relying on intelligence to determine who was responsible for that attack,

\footnotetext{
${ }^{1}$ UN CHARTER, art. 51.
} 
President Bush sent out the FBI to investigate. After about two years, two intelligence operatives of the Libyan government were indicted for the crime. Despite the fact that the Libyan government must have authorized the attack, President Bush took no military action. Instead, he secured resolutions from the Council requiring that the two individuals be surrendered to the United States or the United Kingdom for trial, and that Libya pay compensation to the families of the victims, imposing massive economic sanctions on Libya until it satisfied the resolutions. Years later, Libya finally agreed to surrender the two agents for trial, in the Hague, before Scottish judges. In exchange, the Council sanctions were lifted.

A long period of preparation and trial ensued, ending in the conviction of one agent and the acquittal of the other. An appeal by the convicted individual was rejected. Well over ten years have passed since the indictment, however, and no compensation has yet been paid by Libya. More important, no one expects President Qadaffi or any of his officials to be pursued for a crime they must have approved.

President Clinton used force against Iraq for fomenting a plan to assassinate former President Bush, and against Al Qaeda immediately after the destruction of two U.S. embassies in Africa, but both these uses of force were extremely limited. The first was an attack on a single building housing the Iraqi intelligence service; in the second numerous missiles were fired at a camp at which Al Qaeda officials had held a meeting. Otherwise, the only measures taken against terrorists during the last two presidencies have been several prosecutions of those low-level operatives the United States was fortunate enough to arrest. This policy of dealing with the terrorist threat allowed Osama bin Laden and his leadership, and the state that has given them sanctuary, time to plan, prepare, and implement new attacks of increasing seriousness with impunity.

Prosecutors and investigators were deservedly proud when, on May 29, 2001, a jury in New York ruled that four defendants were guilty of conspiring with Osama bin Laden to bomb American embassies in Nairobi, Kenya, and Dar es Salaam, Tanzania, on August 7 , 1998. ${ }^{2}$ The bombings killed 224 people, including twelve Americans, injured thousands, and caused property and other damage of several hundred million dollars. Convicting responsible individuals establishes that they are subject to the rule of law; brings a sense of justice to survivors and relatives; lends credibility to the pledge that terrorists who kill Americans will be pursued until captured, prosecuted, and punished; and can lead to information helpful in capturing and prosecuting others, preventing future attacks, and exposing the aims and methods of terrorist groups.

But an antiterrorism policy based principally on criminal prosecution has created the misleading impression that the U.S. government is providing the American people with meaningful protection. It is uncomfortably like playing the computer game "Where in the World Is Carmen San Diego?" in which player investigators are assigned cases involving spectacular crimes-for example, stealing the Golden Gate Bridge-committed by members of Carmen's extensive gang. Investigators then dash off to collect evidence, flying from place to place, based on clues received from witnesses and documents. Gradually, a successful investigator puts together enough evidence about the culprit to establish probable cause for an arrest. The investigator must then secure a warrant, and thereafter may arrest the correct person, and only that person, when he or she appears on the screen. Every successful arrest is a win, even though the boss-the daring and elusive Carmen San Diego-remains at large, arranging for other gang members to

\footnotetext{
${ }^{2}$ Benjamin Weiser, The Terror Verdict: The Overview; 4 Guilty in Terror Bombings of 2 U.S. Embassies in Africa; Jury to Weigh 2 Executions, N.Y. TIMES, May 30, 2001, at Al.
} 
commit new crimes. Successful investigators are congratulated and promoted. It is possible to arrest Carmen San Diego herself, but only after all her numerous henchmen have been jailed, after which in any event a reincarnated Carmen San Diego appears, and the game goes on.

\section{Contrasting Objectives}

The ultimate aim of criminal prosecution is to capture and deter those responsible for terrorist attacks. Necessarily, though, each prosecution is of specific individuals who are known to have perpetrated specific crimes. While Osama bin Laden and some of his top associates were indicted along with the four actually tried in 2001, they cannot be reached by the criminal process so long as they stay in Afghanistan, which refuses to extradite or prosecute them.

By contrast, an effort to deal with bin Laden and his group as enemies would focus on bin Laden himself and every other member of Al Qaeda, regardless of their susceptibility to prosecution for particular crimes. The objective would not be convictions of particular $\mathrm{Al}$ Qaeda members, but ending the threat the gang poses.

Reliance on criminal prosecution to combat international terrorism has led after each bin Laden attack to an intensive investigation led by the FBI. Given its aim of arresting and prosecuting the actual perpetrators of each offense, FBI investigators strive to find usable evidence to identify specific suspects; to secure search and arrest warrants; and to extradite and prosecute those brought to trial. To use evidence at trial, moreover, prosecutors have to satisfy rules related to reliability, and the need for usable evidence often leads prosecutors to offer deals to participants who are sometimes more culpable than those actually prosecuted.

An approach that targets bin Laden as an enemy of the United States also requires investigation but it attempts primarily to determine who was ultimately responsible, rather than to build criminal cases against particular perpetrators. The test for evidence is reliability, not admissibility; and the strength of its value is judged, not by any specific legal standard but by whether the evidence justifies the measures the United States considers taking. Deals made with bin Laden's associates would be to obtain cooperation in destroying his capacity to attack the United States, rather than to find evidence to prosecute underlings.

Antiterrorism efforts must ultimately be judged by whether they prevent attacks. Any conceivable deterrent effect of criminal prosecutions of low-level conspirators is lessened by the fact that they take years to complete and may take place after additional attacks. Criminal prosecution seems no more effective against bin Laden and his leadership than the fantasy prosecutions of Carmen San Diego. Law enforcement activity cannot be expected to shut down terrorist organizations operating in hostile and uncooperative states like Afghanistan. Nor is Afghanistan likely to be convinced by successful prosecutions to surrender bin Laden; the Afghan information ministry condemned the embassy bombing convictions as "unfair," and promised not to hand over bin Laden "under any circumstances," calling him "a great holy warrior of Islam and a great benefactor of the Afghan people."

Criminal prosecutions are especially ineffective in deterring fundamentalist terrorist groups able to recruit individuals willing to sacrifice their lives in suicide bombings. These terrorists are not "cowards," as U.S. officials sometimes assert; they are crazed killers, as prepared for sacrifice as good soldiers. Anyway, while some will cooperate

${ }^{3}$ Elusive bin Laden Keeps US at Safe Distance, S. China Morning PoST, June 4, 2001. 
rather than face life imprisonment or death, $\mathrm{Al}$ Qaeda and similar organizations limit the damage any individual can inflict by functioning in loose-knit cells.

To treat bin Laden as an enemy of the United States requires more than the prosecution of underlings, or even a freeze on $\mathrm{Al}$ Qaeda's assets and economic sanctions against Afghanistan. It requires a shift in attitude from one of responding to terrorist attacks as ordinary crimes to one of attempting directly to prevent terrorist groups from carrying out their threats.

Force is the essential method of protection when all else fails. Every recent U.S. president has properly concluded that necessary and proportionate force may lawfully be used in foreign territory to prevent attacks by terrorists given sanctuary there.

But resort to force, even when lawful, does require great care. Mistakes or excessive collateral damage can undermine its effectiveness. While the United States is free to act unilaterally in its self-defense, it must be prepared to defend its actions or to admit and pay for its mistakes. Ultimately, it is not any legal inhibition that accounts for the U.S. policy of prosecuting rather than destroying international terrorist groups. Rather, it is the claim that such attacks lead to reprisals against the United States, creating a cycle of violence, and make terrorists like bin Laden heroes in the eyes of Muslim militants. It is clear that militants who publicly commit themselves to attack U.S. targets are not going to be deterred by criminal prosecutions; they can only be stopped through effective action. The key to success is not merely to attack but to attack until the capacity of a group to commit acts of terror is destroyed. In no form of real warfare would a combatant expect an enemy to cease its attacks merely because of a single, largely symbolic, use of force, such as President Clinton's strike against bin Laden in Afghanistan.

Furthermore, the claim that attacks on terrorists risk violent responses applies equally to criminal prosecutions. A criminal-law strategy is as likely to anger terrorists as attacks aimed at destroying them, and public trials make them heroes in the eyes of militants. Only in the world of computer games can we expect to avoid the real risks of confronting an enemy. 